JURNAL KETAHANAN NASIONAL

ISSN: 0853-9340 (Print), ISSN: 2527-9688 (Online)

Online sejak 28 Desember 2015 di: http:/jurnal.ugm.ac.id/JKN

VOLUME 23

No. 1, 27 April 2017

Halaman 86-103

\title{
Evaluasi Kinerja KKIP Dalam Kerjasama Republik Indonesia-Korea Selatan Pada Pembangunan Kapal Selam Untuk Mendukung Ketahanan Alutsista TNI Angkatan Laut
}

\author{
Tunggul Prasetyo \\ Pusat Pengadaan Badan Sarana Pertanahan Kementrian Pertahanan \\ Email: tunggulprasetyo4@gmail.com \\ Armaidy Armawi \\ Fakultas Filsafat UGM \\ Email: armaidy@ugm.ac.id \\ Dafri Agus Salim \\ Fakultas Fisipol UGM \\ Email: dafri@ugm.ac.id
}

\begin{abstract}
This study was aimed to knew and analyzed the implementation of the cooperation between Republik Indonesia and South Korea in the construction of submarines, to the Navy defense equipment resilience.

The method used by the researchers in this study was a qualitative descriptive method. Data collection techniques used three techniques, in-depth interviews, observation, library and documentation. Objects in this study that the parties involved in the cooperation Indonesia South Korea in the construction of submarines, especially the executive team officials Defence Industry Policy Committee (KKIP).

The results showed that in the implementation of cooperation Indonesia South Korea in the construction of the submarine still lacks the strength of its bargaining Indonesian government, especially KKIP and Defense industry involved in this cooperation program. This was indicated by the presence of the technology transfer process was still below of $85 \%$ as a basis for accelerating the revitalization of the defense industry in achieving the navy defense resilience.
\end{abstract}

Keywords: Evaluation, International Cooperation, Navy Defense Equipment Resilience.

\begin{abstract}
ABSTRAK
Penelitian ini bertujuan untuk mengetahui dan menganalisis pelaksanaan kerjasama yang dilaksanakan indonesia-Korea Selatan dalam Pembangunan Kapal Selam dan mengevaluasi kerjasama Indonesia Korea selatan dalam pembangunan kapal selam terhadap ketahanan alutsista TNI AL.

Metode yang digunakan dalam penelitian adalah metode deskriptif kualitatif. Teknik pengumpulan data menggunakan tiga teknik, yaitu wawancara mendalam, observasi, kepustakaan, serta studi dokumentasi. Objek dalam penelitian ini yaitu para pihak yang terlibat dalam kerjasama Indonesia Korea selatan dalam pembangunan kapal selam, khususnya para pejabat tim pelaksana Komite Kebijakan Industri Pertahanan (KKIP).

Hasil penelitian menunjukkan bahwa dalam pelaksanaan kerjasama indonesia Korea selatan dalam
\end{abstract}


pembangunan kapal selam memiliki kekurangan berupa kekuatan tawar menawar pemerintahan Indonesia, khususnya KKIP maupun Industri Pertahanan yang terlibat dalam program kerjasama tersebut Hal ini ditunjukkan dengan terlaksananya proses alih teknologi yang masih kurang dari angka $85 \%$ sebagai salah satu dasar bagi percepatan revitalisasi industri pertahanan dalam mencapai ketahanan alutsista Angkatan Laut

Kata Kunci: Evaluasi, Kerjasama Internasional, Ketahanan Alutsista TNI Angkatan Laut

\section{PENGANTAR}

Salah satu faktor penting yang dipertimbangkan dalam menenentukan kebijakan pembangunan kekuatan pertahanan adalah kondisi geografi, demografi, sumber kekayaan alam dan buatan serta kondisi sosial termasuk kemampuan keuangan negara. Faktor penting lainnya adalah penguasan teknologi terutama di bidang alat utama sistem senjata (alutsista), ancaman nyata dan potensial yang dihadapi oleh negara serta perkembangan konteks strategis yang meliputi aspek-aspek ideologi, politik, ekonomi dan sosial budaya, ancaman nyata dan potensial yang dihadapi oleh negara, serta perkembangan konteks strategis yang meliputi aspek-aspek ideologi, politik, ekonomi dan sosial budaya (UU Pertahanan Negara 2002; Menteri Pertahanan RI, 2008).

Dipandang dari luas wilayah darat dan perairannya, serta jumlah penduduk, Indonesia dapat disebut sebagai bangsa yang besar, namun demikian kondisi tersebut tidak seimbang dengan jumlah maupun jenis alutsista (alat utama sistem senjata) yang dimilikinya untuk melakukan pengamanan. Tidak lebih kurang dari 5,8 juta $\mathrm{km}^{2}$ luas laut dan panjang garis pantai lebih dari $81.000 \mathrm{~km}$ tentunya membutuhkan dukungan alutsista yang besar dan mampu menjaga kedaulatan perairan yang luas tersebut. Hal ini membawa pemikiran bahwa diperlukannya suatu pengembangan alutsista untuk menghadapi situasi dan perkembangan ancaman maupun bentuk perang yang tidak lagi konvensional.
Saat ini hampir separuh kekuatan alutsista yang dimiliki TNI tidak sanggup beroperasi maksimal. Penyebabnya adalah faktor usia peralatan dan terbatasnya anggaran untuk pengadaan alutsista maupun komponen dan suku cadangnya. Hanya sekitar 40$50 \%$ kesiapan operasional minimum sistem persenjataan TNI saat ini diseluruh matra angkatan. Persentase tersebut jauh di bawah persentase kesiapan minimal operasional TNI (Bakrie, 2007; UU TNI, 2004). Pemerintah memiliki kewajiban untuk menambah dan meremajakan alutsista, terutama alutsista tidak layak pakai yang dapat membahayakan keselamatan prajurit dan pada akhirnya dapat berakibat ancaman pada kedaulatan bangsa.

Namun tentunya penambahan maupun peremajaan alutsista TNI tidak dapat dilaksanakan secara bersamaan mengingat anggaran negara untuk pertahanan masih sangat kecil. Pada anggaran Renstra 2005-2008 ratarata kurang dari 1\% dari Pendapatan Domestik Bruto (PDB) atau kurang dari 5\% dari APBN (Menteri Pertahanan RI, 2008). Jumlah tersebut tidak mengalami kenaikan secara signifikan pada tahun 2009 sampai dengan 2013 yang tidak mencapai 1\% dari PBD (SIPRI, 2014).

Keterbatasan anggaran pertahanan tersebut disikapi oleh Kementerian Pertahanan dan TNI dengan merencanakan pembangungan kekuatan pertahanan secara minimal melalui program Minimum Essential Forces (Peraturan Panglima TNI, 2010). Minimum Essential Forces atau yang dikenal dengan istilah MEF 
merupakan proses untuk memodernisasi alutsista Indonesia yang telah dicanangkan pemerintah sejak tahun 2007. Program MEF tidak hanya mengembangkan alutsista melalui pengadaan alutsista saja namun juga mengembangkan industri pertahanan yang mampu mendukung alutsista tersebut dalam hal ketersediaan suku cadang secara mandiri, pengembangan teknologi maupun pembangunan alutsista secara mandiri (UU Industri Pertahanan, 2012).

Bagi Indonesia, inovasi sistem pembelian peralatan militer penting dilakukan. Dalam rangka mengurangi beban devisa dan efek-efeknya pada neraca pembayaran, serta menstimulasi perkembangan industri pertahanan domestik. Inovasi tersebut harus menjadi bagian dari mekanisme transisi pendanaan pengadaan persenjataan. Karenanya, apabila terdapat kondisi yang dapat menghambat perkembangan postur pertahanan seperti kondisi embargo tidak lagi menjadi hal yang menakutkan.

Seiring dengan modernisasi alutsista TNI dan pengembangan industri pertahanan nasional yang menopang sistem pertahanan secara mandiri, maka peran pemerintah dibutuhkan untuk turut serta membangun pilar industri pertahanan nasional. Pada tahun 2010, Presiden Soesilo Bambang Yoedoyono membentuk Komite Kebijakan Industri Pertahanan (KKIP) yang memiliki tugas untuk merumuskan dan mengevaluasi kebijakan mengenahi pengembangan dan pemanfaatan industri pertahanan.

Kapal selam menjadi salah satu program prioritas modenisasi alutsista TNI Angkatan Laut. Selain memiliki teknologi persenjataan yang tinggi, kapal selam juga memberikan efek deterrence (daya tangkal) terhadap negara lain yang berupaya memasuki perairan nasional
(Murray, 2016). Dengan alokasi anggaran untuk pengadaan 3 unit kapal selam yang sangat besar terbagi dalam dua Rencana Strategis (Renstra) yaitu Renstra I tahun 2004-2009 sebesar 350 juta dollar Amerika Serikat dan Renstra II tahun 2010-2014 sebesar 730 juta dollar Amerika Serikat (Bappenas, 2004), Indonesia berkeinginan untuk menguasai teknologi kapal selam melalui industri dalam negeri.

Bersamaan dengan ditandatanganinya Kontrak Jual Beli Kapal Selam melalui Kontrak Jual Beli Nomor TRAK/1493/XII/2011 tanggal 11 Desember 2011 antara Kementerian Pertahanan dan Daewoo Shipyard Marine Engineering (DSME) Korea Selatan, Presiden Soesilo Bambang Yoedoyono menetapkan kapal selam menjadi salah satu proyek nasional, yang diharapkan Indonesia melalui PT.PAL Indonesia (Persero) melalui kerjasama yang difasiltasi Kementerian Pertahanan dan KKIP mampu kedepannya memenuhi kebutuhan alutsista TNI AL khususnya kapal selam secara mandiri.

Berdasarkan latar belakang di atas maka peneliti tertarik untuk melakukan penelitian dengan judul "Evaluasi Kerjasama Komite Kebijakan Industri Pertahanan (KKIP) Dalam Kerjasama Indonesia-Korea Selatan dalam Pembangunan Kapal Selam untuk Mendukung Ketahanan Alutsista TNI AL". Permasalahan dalam penelitian ini adalah : (1) Bagaimana kinerja KKIP terhadap pelaksanaan kerjasama antara Indonesia dengan Korea Selatan dalam bidang pertahanan? (2) Bagaimana kinerja KKIP dalam mengevaluasi pelaksanaan kerjasama yang dilaksanakan antara Indonesia dengan Korea Selatan dalam pembangunan kapal selam terhadap ketahanan alutsista TNI AL?

Penelitian ini menggunakan pendekatan kualitatif-deskriptif. Lokasi penelitian ini 
bertempat di Komite Kebijakan Industri Pertahanan (KKIP). Nara sumber yang dilibatkan dalam penelitian ini adalah: (1) Wakil Ketua Pelaksana KKIP, (2) Ketua Bidang Alih Teknologi dan Offset KKIP, (3) Staf Ahli KKIP Bidang Sistem Pertahanan Negera, (4) Direktur Jenderal Potensi Pertahanan Kemhan, (5) Koordinator pelatihan kapal selam daari PT PAL Indonesia (Persero).

\section{PEMBAHASAN}

\section{Mekanisme Kerjasama Indonesia-Korea} Selatan Dalam Pembangunan Kapal Selam

Kerjasama pembangunan kapal selam antara Indonesia dan Korea Selatan dilaksanakan dalam satu kontrak perjanjian pengadaan kapal selam Nomor: TRAK/1495/ XII/2011/AL yang ditandatangi pada tanggal 20 Desember 2011. Kontrak jual beli tersebut didasarkan pada kebutuhan TNI Angkatan Laut yang dianggarkan sebesar USD 1,1 juta dengan dua Renstra (Perencanaan Strategis) yaitu Renstra I tahun 2004-2009 sebesar USD 350 juta dan Renstra II tahun 2010-2014 sebesar USD 730 juta (Resume Pengadaan Kapal selam, 2011).

Pengadaan kapal selam ini pada awalnya mengacu kepada kebutuhan TNI Angkatan Laut sesuai tahapan dalam program kebutuhan pokok minimum (Minimum Essential Forces). Kebutuhan ini didasarkan pada minimnya jumlah kapal selam yang dimiliki TNI Angkatan Laut saat ini dan kondisi yang tidak siap operasi dihadapkan pada wilayah perairan Indonesia yang harus diawasi. Pemenuhan tiga unit kapal selam selanjutnya diharapkan hanya dengan mekanisme pembelian, artinya pelaksana pekerjaan akan menyelesaikan pemesanan kapal selam untuk TNI Angkatan Laut tanpa adanya keterikatan dalam bentuk kerja sama alih teknologi.
Pemerintah melalui Komite Kebijakan Industri Pertahanan (KKIP) menyatakan telah menetapkan kapal selam sebagai program prioritas nasional revitalisasi industri pertahanan. Mengingat kapal selam memiliki daya tangkal yang tinggi bagi pertahanan negara. Laksamana Muda TNI (Purn) Rachmad Lubis menyatakan dalam wawancaranya sebagai berikut.

\begin{abstract}
"Kapal selam merupakan satu dari tujuh program nasional, kemudian enam program di antaranya adalah pesawat tempur kemudian tank, lalu rudal kemudian roket lalu kemudian propelan. Nah untuk mendapatkan tujuh program nasional tersebut harus ada tujuh kriteria yang harus dipenuhi salah satunya lintas kementerian, lintas pemerintahan, berteknologi tinggi, bernilai strategis, nah ini yang paling utama nilai strategis, ini terutama berdaya tangkal tinggi. Kemudian juga ada aspek ekonominya terhadap pertumbuhan ekonomi nasional. Nah kapal selam dihadapkan pada tujuh kriteria tersebut memang memenuhi syarat" (Laksamana Muda TNI (Purn) Rachmad Lubis: Kepala Bidang Alih Teknologi dan Offset KKIP, wawancara tanggal 13 April 2016).
\end{abstract}

Mengingat sangat pentingnya nilai strategis kapal selam bagi pertahanan negara perlu adanya strategi khusus dalam pembelian kapal selam. Strategis tersebut yaitu Indonesia tidak hanya mampu membeli namun sebisa mungkin menguasai teknologi kapal selam. Kapal selam memiliki teknologi sangat tinggi dan hanya negara-negara Eropa seperti Jerman, Rusia, Prancis serta Amerika Serikat ataupun Cina dan Turki yang saat ini menguasai teknologi kapal selam.

Dengan daya tangkal tinggi tersebut, negara yang memiliki kapal selam biasanya akan disegani oleh negara lain dan wilayah kedaulatannya akan lebih terjamin 
keamanannya. Lebih lanjut Laksamana Muda TNI (Purn) Rachmad Lubis menyampaikan dalam wawancaranya sebagai berikut.

"Perawatan pertahanan yang didukung dengan kehadiran kapal selam mempunyai daya penangkalan yang sangat tinggi karena sifat sulit dideteksinya itu terutama, itu sebabnya selain di samping memenuhi tujuh kriteria untuk mendapatkan program nasional, kapal selam itu memiliki kemampuan strategis mengapa perlu kita kembangkan" (Laksamana Muda TNI (Purn) Rachmad Lubis: Kepala Bidang Alih Teknologi dan Offset KKIP, wawancara tanggal 13 April 2016).

Kementerian Pertahanan Republik Indonesia menyikapi terlaksananya program nasional kapal selam dengan memasukkan kewajiban kerjasama pada proses pelelangan. Hal ini dilakukan untuk memberikan keterikatan dan kewajiban negara peserta lelang untuk mau memberikan alih teknologi kapal selam kepada Indonesia.

Staf Ahli KKIP Bidang Sistem Pertahanan Negara dalam wawancaranya juga menyampaikan tentang perlunya penguasaan teknologi kapal selam bagi Indonesia, sebagai berikut.

"Kepemilikan kapal selam yang didapat dengan cara membeli memang memiliki daya tangkal yang tinggi tetapi tidak semutlak dengan kapal selam yang diproduksi sendiri oleh Indonesia, sehingga negara lain tidak akan tahu berapa jumlah kapal selam yang dimiliki oleh negara kita secara pasti dan negara lain tidak akan tahu apa kemampuan yang dimiliki oleh negara. Meskipun dengan keterbatasan yang ada, kita perlu maksimalkan program ini sebagai wahana untuk kita mengembangkan industri dalam negeri khususnya di bidang kapal selam (Mayor Jenderal TNI (Purn) Judy Harianto: Staf Ahli KKIP Bidang Sistem
Pertahanan Negara, wawancara tanggal 13 April 2016)

Dalam Risalah lelang kapal selam tahun 2011 diketahui bahwa lelang terbatas pengadaan kapal selam dimulai sejak tahun 2010 di Markas Besar Angkatan Laut. TNI Angkatan Laut mengundang penawaran dari empat Negara yaitu Marine Force International (Inggris), Rossoboronexport (Rusia), DCNS (Perancis) dan Daewoo Shipbuilding Marine Engineering (Korea Selatan). Dari evaluasi yang diadakan oleh Panitia Pengadaan di Kementerian Pertahanan pada tanggal 28 Juni 2011, Korea Selatan dinyatakan sebagai pemenang lelang pengadaan Kapal selam. Selain menawarkan tiga unit kapal selam dengan harga termurah yaitu USD. 1,079,999.00, Korea Selatan juga memberikat spesifikasi teknis yang dibutuhkan TNI Angkatan Laut dan tentunya alih teknologi bagi Indonesia.

Marsekal Madya TNI (Purn) Eris Herryanto yang saat itu menjabat sebagai Sekretaris Jenderal Kementerian Pertahanan mengatakan sebagai berikut.

"Pada saat pengadaan pengguna Angkatan Laut telah mengadakan apa namanya, evaluasi kapal selam dengan fungsi apa saja yang dibutuhkan. Dari situ sesuai dengan sistem pengadaan di kita dilaksanakanlah lelang secara terbuka dengan kriteria bahwa kapal selam yang diadakan harus bisa mengemban fungsi yang dibutuhkan Angkatan Laut. Dari lelang itu ternyata Korea yang lebih unggul baik dari segi pemenuhan dari segi operasional, kesanggupan melaksanaan transfer of technology dan yang paling mencolok kenapa Korea terpilih dari aspek harga yang paling kompetitif. Karena dari anggaran yang ada kalau kita dapatkan dari Negara Eropa seperti itu, mungkin hanya mendapat dua sampai dengan dua setengah kapal 
Tunggul Prasetyo, Armaidy Armawi, Dafri Agus Salim -- Evaluasi Kinerja KKIP Dalam Kerjasama Republik Indonesia-Korea Selatan Pada Pembangunan Kapal Selam

Untuk Mendukung Ketahanan Alutsista TNI Angkatan Laut

selam. Sementara dengan Korea seperti yang telah berjalan selama ini, kita memperoleh tiga unit kapal selam" (Marsekal Madya TNI (Pun) Eris Herryanto: Wakil Ketua KKIP, wawancara tanggal 12 April 2016).

Kontrak pengadaan kapal selam dilaksanakan oleh Kementerian Pertahanan Republik Indonesia selaku Pembeli dengan Daewoo Shipbuilding Marine Engineering (DSME) Korea selaku Penjual. Pada kontrak pengadaan ini selain membahas pasal terkait hak dan kewajiban para pihak untuk melaksanakan ikatan perjanjian, terdapat dua pasal kesepakatan kerjasama untuk melaksanakan Pelatihan dan Produksi Bersama/Joint Production kapal selam yang ketiga sebagai berikut.

Pasal 16.2

PENJUAL harus menyediakan OJT (on the job training) terdiri dari design lecture sebagaimana tercantum dalam Lampiran F. (Kontrak Jual Beli Nomor: TRAK/1495/ XII/2011/AL tanggal 20 Desember 2011).

Sedangkan pasal tentang Joint Production pada kontrak ini disebutkan sebagai berikut:

\section{Pasal 17}

Pihak PEMBELI bertujuan untuk membangun KAPAL SELAM KETIGA di GALANGAN KAPAL LOKAL

Pihak PENJUAL harus mendiskusikan dan menyetujui dengan Pihak PEMBELI untuk memaksimalkan Transfer of Technology (ToT) dan lingkup pekerjaan produksi KAPAL SELAM KETIGA dan GALANGAN KAPAL LOKAL sesuai kemampuan kemampuan GALANGAN KAPAL LOKAL, seperti sumber daya manusia, tingkat teknologi, fasilitas yang diperlukan, sistem peralatan, investasi dan lain-lain. Keputusan mengenahi kemampuan GALANGAN KAPAL LOKAL harus dinilai oleh Konsultan Independen.

Dalam hal ini kedua belah PIHAK harus mendiskusikan dan menyetujui untuk membangun KAPAL SELAM KETIGA bersama sama Pihak PENJUAL di Korea dan GALANGAN KAPAL LOKAL di Indonesia yang sesuai dalam Lampiran G. (Kontrak Jual Beli Nomor: TRAK/1495/XII/2011/AL tanggal 20 Desember 2011).

Dua pasal di atas pada kontrak menyebutkan bahwa Daewoo Shipbuilding Marine Engineering (DSME) Korea bersedia untuk memberikan teknologi pembangunan kapal selam melalui skema joint production pada pembangunan kapal selam ketiga serta pelatihan kepada personel dari galangan kapal dalam negeri. Galangan Lokal yang dimaksud dalam kontrak tersebut yaitu PT. PAL Indonesia (Persero), sesuai Surat Keputusan Ketua Harian KKIP Nomor: KEP/15/KKIP/XII/2013 tanggal 17 Desember 2013.

Ketua Project Officer Matra Laut, Laksamana Pertama TNI Suryo Djati Prabowo menyampaikan tentang mekanisme kerjasama kapal selam sebagai berikut.

"Tiga unit kapal selam itu mekanismenya adalah pertama transfer of technology yaitu pada saat perancangan dan perekayasaan kapal selam satu dan dua itu dijadikan sarana untuk pembelajaran bagi peserta dari PT.PAL, kemudian pada kapal selam ketiga itu pembangunannya dalam bentuk blok blok itu dilaksanakan di Korea tetapi teknisi teknisi PT.PAL sudah ikut berpartisipasi, kemudian nanti perangkaiannya dilaksanakan di PT.PAL" (Laksamana Pertama TNI Suryo Djati Prabowo, Ketua Project Officer Katra Laut: wawancara tanggal 7 April 2016). 
Pada tahapan kerjasama ini, Indonesia sudah dilibatkan pembangunan kapal selam sejak kapal pertama. Mengingat gambar menjadi sesuatu yang sangat kritikal dalam pembangunan kapal selam, maka peserta design lecturer memperoleh porsi pelatihan yang lebih dibandingkan peserta yang melaksanakan pelistrikan, pengelasan, pengabelan. Pada pembangunan kapal selam di Korea, dari puhak Indonesia tidak hanya PT.PAL Indonesia (Persero) yang dilibatkan namun juga dari PT. Barata maupun Tim dari Badan Pengkajian dan Penerapan Teknologi (BPPT).

Skema pembangunan kapal selam terbagi dalam Local Production/Joint Production yaitu section \#30 dan \#40 di produksi di PT. PAL, sedangkan section \#10, \#20 dan \#50 sistem senjata dan sistem pendorong di produksi di DSME, kemudian final assembly sampai dengan di PT. PAL Indonesia, sebagaimana ditunjukkan dalam gambar 1 di bawah ini.

Pertimbangan pembagian tersebut adalah sebagai berikut

Pertama, penguasaan teknologi pembangunan kapal selam baik skill maupun manajemen proyek secara kuantitatif dapat diserap oleh tenaga kerja Indonesia minimal $60 \%$, hal ini dapat dijadikan sebagai bekal awal dalam menangani proyek pembangunan kapal selam yang akan datang.

Bapak BJ. Habibie selaku Koordinator pelatihan Design Lecture di Korea mengatakan ketika ditanya seberapa besar penyerapan dari on the Job Training untuk membangun kapal selam, sebagai berikut.

\begin{abstract}
"Mengingat peserta yang diberangkatkan untuk melaksanakan OJT merupakan orang orang terbaik PT. PAL, kami optimis mampu menyerap ilmu yang diperoleh lebih dari 80\%. Namun kami mengharapkan bahwa untuk memaintenance keahlian kami, perlu dukungan agar kapal ketiga tetap dibangun di sini dengan skema joint section. (Habibie, Koordinator Design Lecturer PT.PAL Indonesia (Persero), Wawancara tanggal 12 April 2016)
\end{abstract}

Kedua, skema whole local production memerlukan tambahan waktu delivery $\pm 1,5$ tahun dan penambahan biaya produksi yang cukup signifikan, sedangkan skema Joint Production diharapkan dapat mengurangi potensi keterlambatan delivery time kapal sesuai analisis dari konsultan DWL(Daewoo logistic).

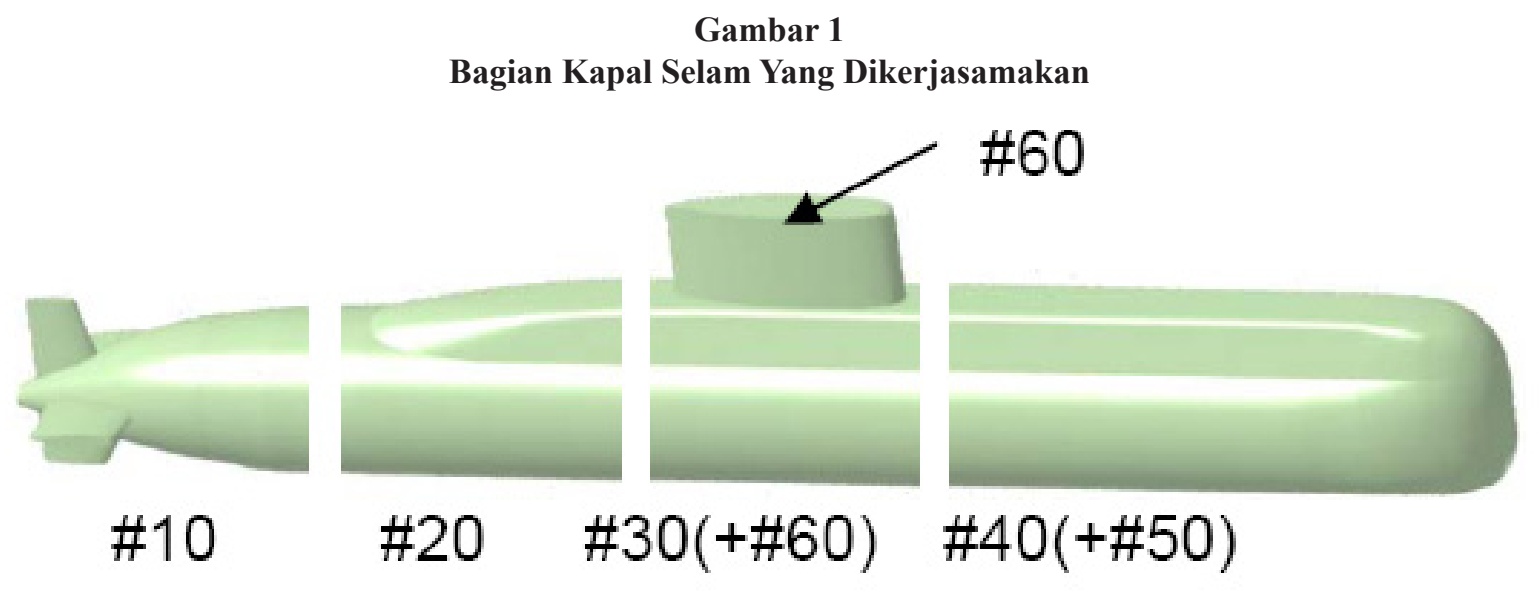

Sumber: Lampiran G Kontrak Nomor: TRAK/1495/KE/XII/ AL tanggal 20 Desember 2011 
Gambar 2

Prosedur Program On the Job Training

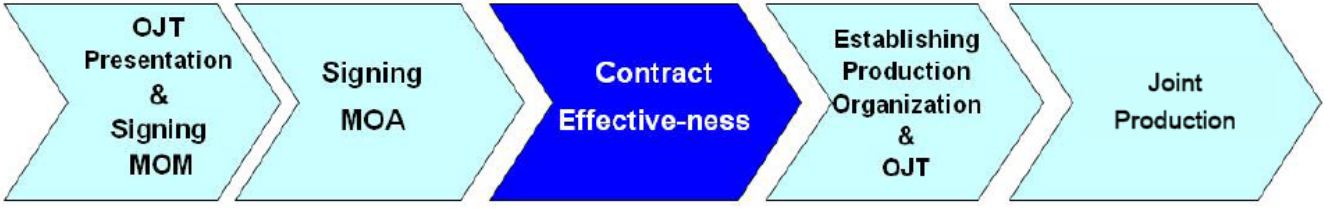

Sumber: Kontrak Pengadaan kapal selam, 2011

Ketiga, fasilitas dan sarana prasarana serta peralatan yang sudah disiapkan oleh PT.PAL dapat dimanfaatkan untuk produksi section dan final assembly (infrastruktur tidak useless).

Keempat, secara strategis dan politis, kapal diluncurkan dari galangan Indonesia. Hal ini sebagai bukti pertanggungjawaban tehadap pemerintah dan DPR atas dukungan politis dan anggaran dalam rangka pemberdayaan industri pertahanan.

Kelima, melaksanakan pembahasan amandemen kontra dan Joint Operation Agreement dengan DSME sesuai dengan skema yang digarapkan oleh pemerintah Indonesia.

Sesuai Lampiran F pada kontrak pengadaan maka para peserta pelatihan dari PT.PAL Indonesia (Persero) akan melaksanakan tahapan-tahapan dari mulai penyiapan dan seleksi personel yang akan On the Job Training, penyelenggaraan pelatihan di galangan DSME Korea untuk melaksanakan On the Job training pada kapal pertama dan kedua sampai dengan turut serta pada pelaksanaan Joint Production di PT.PAL Indonesia (Persero) Surabaya. Selama pelatihan di Korea para peserta pelatihan akan mengikuti pola pekerja Galangan Kapal, sehingga pada saat kembali dari Korea, manajemen kerja para pekerja Korea sudah dimiliki oleh peserta dari PT. PAL Indonesia (Persero). Ini ditunjukkan dalam gambar 2.
Data dalam gambar 2 di atas menunjukkan bahwa kerjasama pembuatan kapal selam Indonesia ini pun sebagian akan dikerjakan di Korea Selatan dan sebagian lagi di kerjakan di Indonesia sebagai bagian transfer of technology. Dua unit kapal selam Indonesia ini akan dikerjakan di Korea Selatan, dimana unit pertama akan dikerjakan seluruhnya oleh ahli Korea Selatan. Unit kedua akan dikerjakan juga di Korea Selatan dengan melibatkan ahli Korea Selatan dan Indonesia. Sedangkan unit ketiga kapal selam Indonesia ini akan dikerjakan di Indonesia oleh tenaga ahli Indonesia dengan dibantu oleh ahli dari Korea Selatan.

Dalam kerjasama tersebut melibatkan transfer teknologi dimana Kemhan berusaha mengirimkan sebanyak 52 sampai dengan 104 teknisi ke Korea Selatan untuk menyelesaikan pembangunan kapal selam pertama, namun baru 90 teknisi yang disetujui. Teknisi tersebut berasal dari TNI Angkatan Laut sebagai pengguna, Kementerian Riset dan Teknologi, dan industri-industri terkait dalam pembangunan kapal selam. Bentuk pembekalan berupa pelatihan dan transfer of technology (ToT), sebagaimana tampak dalam tabel 1.

Dengan demikian tenaga-tenaga ahli yang dikirim pemerintah tidak hanya sebatas learning by seeing (belajar dengan cara mengamati), namun juga learning by doing (belajar dengan cara mempraktikkan). 
Tabel 1

Organisasi Pelatihan

\begin{tabular}{|c|c|c|c|c|c|}
\hline \multirow{2}{*}{ No } & \multirow{2}{*}{ Bidang } & \multicolumn{4}{|c|}{ Jumlah Peserta } \\
\hline & & Manajer & Staf & Koorinator & Pekerja \\
\hline 1 & Manajemen Produksi & $1-2$ & $4-8$ & & \\
\hline 2 & Manajaemen Kualitas & $1-2$ & $4-8$ & & \\
\hline \multirow[t]{7}{*}{3} & Produsi Kapal & & & & \\
\hline & Lambung Kapal & $1-2$ & $1-2$ & $2-4$ & $6-12$ \\
\hline & Permesinan & $1-2$ & $1-2$ & & $4-8$ \\
\hline & Penyambungan & & $1-2$ & $1-2$ & $3-6$ \\
\hline & Pemipaan & & $1-2$ & $1-2$ & $2-4$ \\
\hline & Pelistrikan Komunikasi Senjata & & $1-2$ & $1-2$ & $3-6$ \\
\hline & Pengecatan & & $1-2$ & $2-4$ & $2-4$ \\
\hline 4 & Manajemen Material & $1-2$ & $1-2$ & $1-2$ & \\
\hline \multirow[t]{3}{*}{5} & GRP & & $1-2$ & $1-2$ & $2-4$ \\
\hline & Jumlah Peserta Per Bidang & $5-10$ & $16-32$ & $9-18$ & $22-44$ \\
\hline & Jumlah Keseluruhan & \multicolumn{4}{|c|}{$52-104$} \\
\hline
\end{tabular}

Sumber: Lampiran F Kontrak Jual Beli Pengadaan kapal selam, 2011

Evaluasi Kerjasama Indonesia Korea Selatan Dalam Pembangunan Kapal Selam

Pada Buku Putih Pertahanan (Menteri Pertahanan RI, 2008) menyebutkan bahwa Korea Selatan menjadi mitra yang sangat penting bagi Indonesia dalam membangun kapabilitas pertahanan dan peningkatan profesionalisme prajurit TNI. Pembangunan kapabilitas pertahanan nampak dengan penerimaan alutsista kepada TNI hasil kerjasama dengan Korea Selatan di antaranya penerimaan hibah kendaraan tempur amfibi LVT-7A, overhaul kapal selam KRI Cakra-402 pada tahun 2003 maupun pembangunan kapal Landing Platform Deck (LPD) pada tahun 2004.

Pada pembangunan kapal selam kerjasama Indonesia dan Korea Selatan, evaluasi kerjasama dilakukan dengan melihat pada dokumentasi berupa Laporan hasil kemajuan bulan terakhir pada bulan April tahun 2016 tentang pembangunan tiga unit kapal selam yang disusun oleh Komite Kebijakan Industri Pertahanan (KKIP). Komite Kebijakan Industri Pertahanan dalam memonitor pelaksanaan kerjasama pembangunan kapal selam membagi menjadi 3 bidang yaitu: produksi, pelatihan serta administrasi dan logistik.

\section{Bidang Produksi}

Sesuai kontrak jual beli Nomor TRAK/1493/XII/2011 tanggal 11 Desember 2011, Indonesia dan Korea Selatan sepakat membangun 3 unit kapal selam dengan mekanisme Joint Production. Dua unit kapal selam akan diserahkan di Korea selatan dengan pengerjaan seluruh bagian kapal selam dilaksanakan di Korea Selatan dengan jangka waktu Kapal I nomor lambung H7712 selama 52 bulan (tanggal 9 Maret 2017) dari Kontrak Efektif tanggal 9 November 2012. Kapal ke II dengan nomor lambung H7713 diserahkan 59 bulan atau tanggal 9 Mei 2017 sedangkan 
kapal ke III nomor lambung H7714 diserahkan selama 73 bulan atau tanggal 9 Desember 2018.

Keseluruhan proses produksi untuk Kapal I dan Kapal II dilaksanakan di galangan DSME Korea Selatan, di mana Pihak Indonesia dilibatkan dalam proses pelatihan pembangunan kapal selam. Sedangkan produksi kapal III akan dilaksanakan di dua tempat yaitu Galangan kapal DSME Korea Selatan dan galangan Kapal PT. PAL Indonesia (Persero) Surabaya. Pembangunan bagian badan kapal selam akan dibangun di Korea Selatan selanjutnya untuk penyambungannya akan dilaksanakan di PT.PAL Surabaya sampai dengan launching kapal selam.

Sesuai kontrak, pembangunan dibagi menjadi dua bagian yaitu Basic Design atau rancangan dasar pembangunan kapal selam. Dari keseluruhan 50 gambar, baik Indonesia dan Korea Selatan sudah menyelesaikan keseluruhan. Sedangkan untuk design engineering atau gambar permesinan telah tercapai 95,65.

Tabel 2

Progres Kemajuan Pembangunan Kapal Selam Bulan Maret 2016

\begin{tabular}{lccc}
\hline $\begin{array}{c}\text { No Lambung } \\
\text { kapal }\end{array}$ & Perencanaan & Terlaksana & Deviasi \\
\hline H7712 & $95,60 \%$ & 95,90 & $+0,30$ \\
H7713 & 59,10 & 59,50 & $+0,40$ \\
H7714 & 23,50 & 25,30 & $+1,80$ \\
\hline
\end{tabular}

Sumber: Laporan KKIP Bulan Maret 2016

Dari data tabel 2 di atas dapat disimpulkan bahwa pelaksanaan kerjasama pembangunan kapal selam kedua negara sangat baik dengan deviasi pembangungan ketiga kapal selam menunjukkan angka positif sehingga untuk kapal pertama dengan target penyerahan 53 bulan akan terpenuhi. Hal ini dibuktikan kegiatan launching kapal selam pertama telah terlaksana pada tanggal 24 Maret 2016 (Laporan KKIP bulan Maret 2016)..

Laksamana Muda TNI (Purn) Rachmad Lubis menyampaikan bahwa keberhasilan kerjasama ini akan memberikan efek positif terhadap kerjasama lanjutan kapal selam dalam wawancaranya sebagai berikut.

\section{"Korea selama ini kita pantau itikad baiknya, benarkah dia betul betul mitra yang baik bagi kita seperti itu. Karena kita akan membutuhkan 12 kapal selam baru,sehingga kalau dengan Korea ini kita bisa tahu betul betul sebagai mitra yang tulus di dalam kerjasama, bisa jadi Korea Selatan salah satu kandidat dalam jangka panjang akan menjadi mitra kita untuk membangun melengkapi kapal selam sejumlah 12 kapal selam" (Laksamana Muda TNI (Purn) Rachmad Lubis: Ketua Bidang Transfer of Technology dan Offset KKIP, wawancara tanggal 12 April 2016).}

Indonesia membutuhkan setidaknya 12 kapal selam dihadapkan dengan luas perairan yang ada. Pada Renstra 2015 sampai dengan 2019, Indonesia akan menambah dua unit kapal selam. Keberhasilan kerjasama pembangunan kapal selam Indonesia saat ini tentunya akan menambah keyakinan untuk melakukan kerjasama dengan porsi transfer of technology yang lebih besar bagi Indonesia. Bagi Korea Selatan tentunya juga akan menguntungkan dengan penambahan devisa bagi Korea Selatan.

\section{Bidang Pelatihan}

Dalam kerjasama pembangunan kapal selam Korea Selatan dan Indonesia, pelatihan menjadi hal utama dalam perjanjian kerjasama. Hal ini mengingat sumber daya manusia yang belum mampu dalam pembangunan kapal selam. Hal ini selanjutnya akan diuraikan dalam hasil wawancara sebagai berikut. 
"Dalam industri pertahanan, Indonesia masih tertinggal jauh dalam bidang teknologi dibandingkan negara-negara Eropa. Transfer of Technology menjadi bagian yang sangat diperhitungkan dalam memilih calon penyedia kapal selam. Dan dari calon yang ada, Korea waktu itu yang menawarkan proses TOT (transfer of technology) dengan perusahaan di Indonesia selain harga mereka lebih murah", (Wawancara dengan Laksda TNI (Purn) Rachmad Lubis, tanggal 4 April 2016).

Dari wawancara di atas, Indonesia bermaksud mengejar ketertinggalan teknologi dengan mengedepankan pelatihan terhadap sumber daya manusia PT.PAL Indoensia (Persero) atauupun stake holder yang terkait dalam pembangunan kapal. Saat ini, sumber daya manusia PT.PAL hanya memiliki kemampuan membangun kapal-kapal atas air yang sangat berbeda dengan teknologi pada kapal selam.

Pada kontrak pengadaan kapal selam, pelatihan dituangkan dalam satu lampiran kontrak yakni Lampiran F. Dalam lampiran tersebut, diuraikan bagian apa saja yang yang dilaksanakan pelatihan dan berapa personel yang akan dilibatkan dalam pelatihan. Dari data pada kontrak.

\section{Implikasinya Terhadap Ketahanan Alutsista TNI AL}

Salah satu upaya negara membangun ketahanan alutsista adalah dengan menyediakan dan melengkapi secara berkelanjutan persenjataan bagi pasukan militer mereka untuk melindungi seluruh warga negara beserta aset negara. Untuk memenuhi kebutuhan persenjataan/alustsista dibutuhkan anggaran yang sangat besar. Mengingat peralatan militer sangat mahal, semakin tinggi teknologi persenjataan semakin dibutuhkan anggaran yang lebih besar.
Ketersediaan anggaran yang memadai menjadi salah satu faktor penting dalam peningkatan ketahanan alutsista suatu negara. Pada data yang diolah dari Stockholm International Peace Research Institute, belanja pertahanan Indonesia sampai dengan tahun 2014 masih di bawah Negara Negara Kawasan Asia Tenggara secara prosentase GDP, yaitu di bawah 1\%. Bahkan untuk negara-negara yang relatif luasan wilayahnya lebih kecil dibandingkan Indonesia seperti Brunei, Myanmar, Vietnam dan Singapura mengalokasikan anggaran pertahanannya di atas $2 \%$ dari GDP. Ini dapat dilihat dalam gambar 3.

Pada gambar 3 juga diketahui bahwa Indonesia juga paling sedikit belanja persenjataan secara prosentase. Pada tahun 2014, rata-rata Negara ASEAN menggunakan lebih dari 5\% untuk pembelian persenjataan, Indonesia hanya mencapai angka 4,1\% dari total belanja pemerintah. Hal inilah yang menjadi evaluasi pembangungan ketahanan alutsista di Indonesia, sebagaimana hasil wawancara sebagai berikut.

"Kebutuhan TNI dan Polri itu ada 1200 jenis (alutsista), sangat sangat banyak, ada yang teknologi rendah sampai dengan teknologi tinggi. Dari 1200 itu kita pilah-pilah lagi, mana yang untuk kita bisa fokuskan karena terbatasnya anggaran. Seingat saya antara 18 (jenis) sampai dengan 24 (jenis)" (Wawancara dengan Marsdya TNI (Purn) Eris Herryanto, tanggal 4 April 2016.

Dari yang disampaikan oleh Wakil Ketua KKIP tersebut dapat disimpulkan bahwa TNI/Polri hanya menambah alutsista sebesar $1 \%$ pertahun. Hal ini tentu sangat rawan dari pencapaian ketahanan itu sendiri. Mengingat postur pertahanan merupakan refleksi kekuatan pertahanan yang mencakup 
Gambar 3

Tabel Belanja Pertahanan Negara ASEAN Tahun 2014

Defense Spending as a \% of GDP and Total Government Spending, 2014

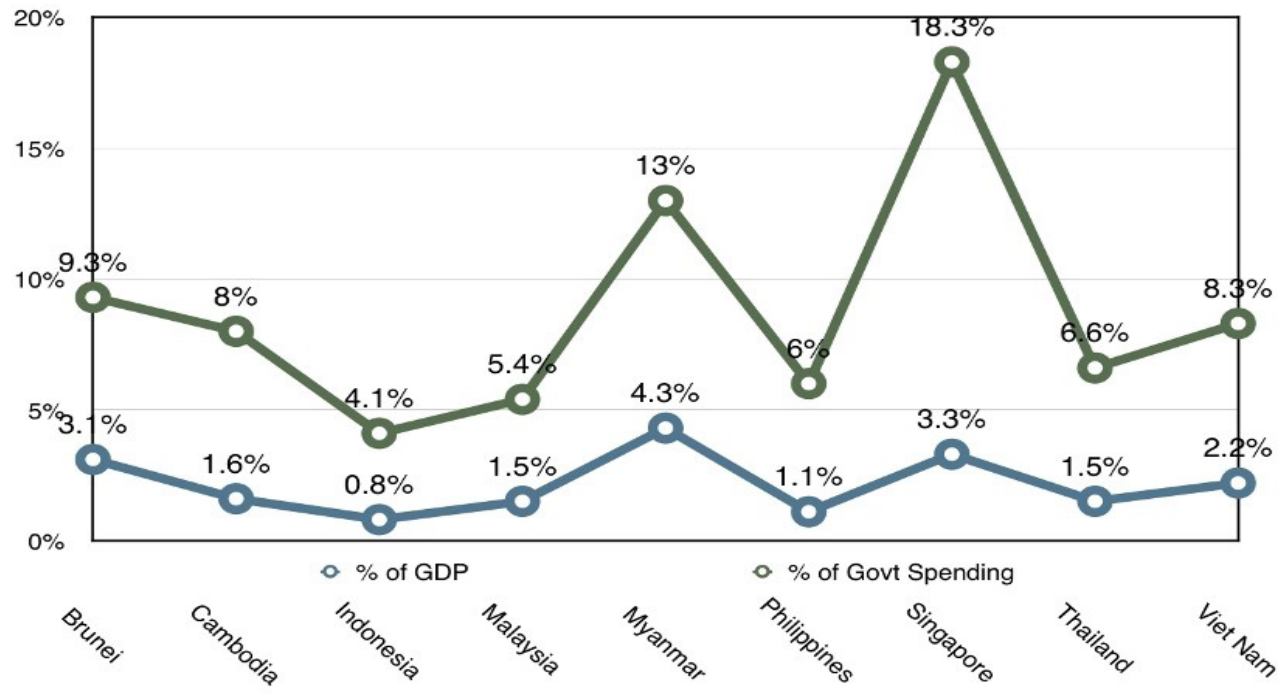

Sumber: Stockholm International Peace Research Institute (SIPRI) Tahun 2014

kemampuan, kekuatan, gelar kekuatan, serta sumber-sumber daya nasional.

\section{Minimum Essential Forces adalah} kekuatan pertahanan minimal yang mampu menimbulkan dampak penangkalan untuk mengatasi ancaman keamanan yang bersifat mendesak. Minimum Essential Forces merupakan suatu kekuatan standar dan minimum TNI yang mutlak disiapkan sebagai prasyarat utama serta mendasar bagi terlaksananya secara efektif tugas pokok dan fungsi TNI

Namun dihadapkan pada kemampuan anggaran negara, serta kemungkinan ancaman berupa invasi asing relatif kecil, maka pembangungan kekuatan pertahanan lebih difokuskan untuk membangun kekuatan Minimum Required Essential Force di mana arah dan sasaran pembangunan pertahanan negara bukan untuk memperbesar kekuatan, melainkan dalam rangka mengisi kesenjangan. Yang dimaksudkan adalah kekuatan dan kemampuan TNI yang diperlukan untuk mengatasi ancaman keamanan yang bersifat mendesak.

\section{Ketersediaan Alutsista}

Berdasarkan dokumentasi pada pembangunan kekuatan minimum TNI tahun 2014-2024 menunjukkan bahwa pemenuhan tujuan ketersediaan alutsista didasarkan atas permasalahan vital yang selama ini terjadi, yaitu penggunaan atau pengadaan alutsista yang belum mencerminkan keterpaduan matra. Dalam mengimplementasikan perwujudan kekuatan Trimatra Terpadu, TNI tidak terlepas dari kemampuan alutsista yang dapat disinergikan dalam kekuatan keterpaduan matra, agar mampu mewujudkan daya tangkal yang tinggi dalam merespon ancaman.

Untuk itu dalam mekanisme pengadaan alutsista harus mencerminkan kepentingan Trimatra Terpadu, dan berorientasi pada keleluasaan kepentingan serta kemampuan matra yang selanjutnya dapat diakomodir pada strata Mabes TNI. Kepentingan alutsista matra tersebut disinergikan menjadi kepentingan Trimatra Terpadu, sehingga penggelaran alutsista TNI akan mencerminkan keterpaduan yang akan saling mendukung antar matra. 
Salah satu yang dikembangkan adalah penggelaran kekuatan Radar TNI AU yang diimbangi dengan gelar satuan Arhanud TNI AD serta berkaitan dengan unsur TNI AL di wilayah.

Berdasarkan hasil wawancara dengan wakil Ketua Tim Pelaksana KKIP, Marsdya TNI (Purn) Eris Heryyanto menunjukkan bahwa untuk saat ini kapal selam yang sudah bisa diterima dan dioperasionalkan oleh pihak pemerintah Indonesia baru dua kapal dari tiga kapal yang seharusnya, sementara satu kapal yang sedianya menjadi bentuk TOT masih mengalami hambatan karena belum terpenuhinya beberapa spesifikasi sesuai yang disyaratkan oleh Korea Selatan. Pihak Korea Selatan memberikan prasyarat sebagai bentuk penjaminan mutu, sehingga di satu sisi ini sebenarnya memberikan keuntungan bagi pihak Indonesia. Namun di sisi lain karena pihak Indonesia sendiri belum memenuhi prasyarat tersebut maka justru mendatangkan hambatan bagi pembangunan kapal selam ke tiga. Untuk wawancara lebih lengkap diuraikan sebagai berikut.

Untuk 2 kapal selam yang dikerjasamakan dengan pihak Korea, TNI AL akan memperoleh kapal yang siap untuk melaksanakan operasi, mengingat 2 unit kapal yang dibangun di Korea dan 1 kapal dilaksanakan joint production di PT PAL tersebut digaransi oleh galangan kapal DSME. Namun untuk PT PAL dalam rangka ketahanan industri, PT PAL dalam membangun kapal selam masih diperlukan kerja sama secara berjenjang dan berkelanjutan sampai dengan mencapai kemandirian. Makanya untuk projek pengadaan ke depan seperti yang telah dituangkan dalam blue book 2015-2019 TNI AL akan mendapatkan lagi 2 tambahan kapal selam. Diharapkan, untuk mencapai ketahanan secara menyeluruh alutsista kapal selam yang diproduksi oleh PT PAL, maka kebijakan harus mampu mengawal proses berjenjang dan berkelanjutan yang saat ini dilaksanakan oleh PT PAL (Wawancara wakil Ketua Tim Pelaksana KKIP, Marsdya TNI (Purn) Eris Herryanto tanggal 5 April 2016)

Hasil analisis di atas menunjukkan bahwa evaluasi terhadap kebutuhan tujuan pemenuhan alutsista terpenuhi. Pemahaman mengenai tujuan pemenuhan alutsista di dasarkan pada kebutuhan Indonesia dalam merespon berbagai kondisi yang menunjang keamanan dengan memenuhi dengan Trimatra Terpadu, dan berorientasi pada keleluasaan kepentingan serta kemampuan matra yang selanjutnya dapat diakomodir pada strata Mabes TNI. Dalam analisis ini diketahui bahwa evaluasi terhadap kebutuhan tujuan pemenuhan alutsista terpenuhi dengan tersedianya dua kapal dari tiga kapal yang seharusnya. Sementara satu kapal yang sedianya menjadi bentuk TOT masih mengalami hambatan karena belum terpenuhinya beberapa spesifikasi sesuai yang disyaratkan oleh Korea Selatan.

\section{Keberlanjutan Alutsista}

Evaluasi terhadap pemenuhan tujuan keberlanjutan alutsista didasarkan pada peningkatan kemampuan Indonesia baik dari segi penguasaan teknologi, sumber daya manusia maupun dukungan finansial. Evaluasi ini merupakan bagian dari pembangunan alutsista secara mandiri.

Berdasarkan hasil wawancara dengan Bapak Habibie, Peserta OJT Design Lecture di Korea Selatan diketahui bahwa keberlanjutan akan pembangunan kapal selam selepas kerjasama ini dimungkinkan untuk dilaksanakan dengan indikasi tersedianya berbagai fasilitas yang menunjang apabila pemerintah Indonesia berkehendak untuk 
Tunggul Prasetyo, Armaidy Armawi, Dafri Agus Salim -- Evaluasi Kinerja KKIP Dalam Kerjasama Republik Indonesia-Korea Selatan Pada Pembangunan Kapal Selam

Untuk Mendukung Ketahanan Alutsista TNI Angkatan Laut

melaksanakan pembangunan kapal selam secara mandiri.

"Dengan infrastruktur yang sedang dibangun oleh PT.PAL saat ini selesai, maka ke depan kapal selam dengan tipe yang sejenis dapat dibangun di fasilitas galangan yang dimiliki PT.PAL. Hal ini mengingat peralatan yang disuplai oleh pihak Korea seperti Pressure Hull Equipment merupakan salah satu bagian yang sangat penting dalam membangun badan kapal selam. Namun demikian tentunya kemampuan PT.PAL tidak hanya dari sisi infratruktur namun juga dari kesiapan SDM yang telah melaksanakan OJT di Korea." (Wawancara dengan Bapak Habibie, Peserta OJT Korea, 12 April 2016)

Hasil wawancara di atas menunjukkan bahwa secara kondisi ideal pelaksanaan kerjasama Indonesia dengan Korea Selatan sebenarnya memberikan pemenuhan tujuan ketahanan secara mandiri namun pada kenyataannya pelaksanaan kerjasama tersebut mengalami berbagai hambatan.

Sementara hasil wawancara dengan Dr. Timbul Siahaan menunjukkan bahwa terdapat hambatan yang ditemui sehingga pembangunan kapal selam secara mandiri masih belum dapat dilaksanakan selepas kerjasama Indonesia-Korea Selatan tersebut. Hasil wawancara diuraikan sebagai berikut.

\footnotetext{
"Mengingat sampai dengan saat ini material untuk membuat kapal selam belum dapat disuplai dari dalam negeri. Salah satu contoh plat baja untuk bangunan kapal selam, Korea sendiri masih mengandalkan impor dari Jerman. PT. Krakatau Steel mungkin memiliki kemampuan untuk melakukan roll terhadap baja namun material sendiri berupa plat baja masih harus diimpor" (Wawancara dengan Dr. Timbul Siahaan, Dirjen Pothan Kemhan, 5 April 2016).
}

Hasil wawancara lain menunjukkan bahwa hambatan yang dimakud adalah (1) bahan yaitu baja yang belum dapat diproduksi oleh PT. Krakatau Steel (2) kurangnya pendanaan (3) penguasaan manajemen baik secara sumber daya manusia maupun teknologi yang kurang (4) kurangnya dukungan dari pemerintah terutama mengenai payung hukum. Hal ini selanjutnya diuraikan dalam hasil wawancara sebagai berikut.

\begin{abstract}
"Secara umum galangan akan mampu melaksanakan pembangunan kapal selam apabila memiliki: 1. Infrastruktur: 2. Teknologi 3. Material 4. Manajemen didukung dengan kebijakan pemerintah, sehingga apabila ada salah satu unsur tersebut belum dapat dipenuhi oleh galangan maka ketahanan dapat dikatakan kurang. Korea Selatan dianggap memliki ketahanan alutsista yang lebih besar, mengingat seluruh material disuplai dari dalam negerinya sendiri, sementara Indonesia saat ini secara material belum dapat didukung dari dalam negeri.Dalam penganggaran terhadap infrastruktur, Pemerintah masih belum sepenuhnya mendukung dikarenakan keterbatasan anggaran. Dari 250 juta USD untuk pembangunan infrastrukur, pemerintah melalui PMN hanya menyediakan 150 juta yang digunakan sebagian untuk membiayai pemberangkatan personel PT PAL untuk melaksanakan OJT di Korea." (Wawancara dengan Laksda TNI (Purn) Rachmad Lubis, tanggal 4 April 2016)
\end{abstract}

Dalam hasil wawancara dengan Laksda TNI (Purn) Rachmad Lubis selaku Ketua Bidang Alih Teknologi dan Offset lain juga menunjukkan bahwa selama proses kerjasama maka TOT tidak dapat berjalan dengan baik karena spesifikasi SDM yang disyaratkan oleh Korea Selatan tidak dapat dipenuhi, sehingga ketika pengiriman personil mengalami hambatan. Hal ini diuraikan dalam hasil wawancara sebagai berikut. 
"Permasalahan yang ada seperti keterlambatan peserta bisa hadir di Korea untuk mengikuti OJT (Learning by seeing) saat pelaksanaan pembangunan kapal selam di galangan, yag mungkin jadwalnya seharusnya sesuai schedule yang tertuang dalam sylabus, namun pada akhirnya mereka hadir setelah sylabus tersebut tengah atau selesai terlaksana. Mengingat peserta yang melaksanakan OJT di Korea diharapkan mampu turut terlibat dalam Joint Production di PT PAL. Namun demikian tidak seluruhnya tidak dapat dilaksanakan namun PT PAL perlu mengejar ketinggalan pelaksanaan OJT tersebut." (Wawancara dengan Bapak Habibie, Peserta OJT Korea Selatan tanggal 12 April 2016).

Hasil analisis data di atas menunjukkan bahwa evaluasi terhadap pemenuhan tujuan keberlanjutan alutsista tidak dapat dipenuhi. Keberlanjutan alutsista tersebut mengacu kepada pemahamam pengembangan kemampuan industri pertahanan Indonesia membangun kapal selam selepas dari kerjasama Indonesia-Korea Selatan. Hal ini disebabkan oleh (1) bahan yaitu baja yang belum dapat diproduksi oleh PT. Krakatau Steel (2) kurangnya pendanaan (3) penguasaan manajemen baik secara SDM maupun teknologi yang kurang.

\section{Ketahanan Alutsista}

Ketahanan alutsista dalam analisis ini didasarkan pada kemandirian industri pertahanan baik dalam memproduksi, menggunakan, dan merawat pertahanan alutsista. Hal ini menjadi salah satu tujuan dalam pelaksanaaan kerjasama IndonesiaKorea Selatan yaitu tidak hanya memenuhi kebutuhan kapal selam itu sendiri, namun juga mengembangkan kemampuan industri pertahanan dalam memproduksi dan merawat.
Dalam hal lain juga ketahanan alutsista didasarkan pada produksi yang dikembangkan oleh industri pertahanan Indonesia diharapkan dapat digunakan memenuhi kebutuhan TNI sendiri.

Lebih lanjut, hasil wawancara dengan Kolonel Laut Oki Samudra, SE MM menunjukkan bahwa evaluasi terhadap pemenuhan tujuan ketahanan alutsista belum terpenuhi. Hal ini sebenarnya merupakan konsekuensi dari hambatan yang ditemui dari evaluasi terhadap keberlanjutan alutsista di atas. Apabila ke depan segala hambatan baik dari faktor teknis maupun prosedur dapat diatasi maka berdasarkan ketahanan alutsista dapat terwujud. Untuk saat ini maka secara prosentase rata-rata mungkin PT.PAL tidak sampai memiliki tidak sampai $50 \%$ kemampuan teknologi dalam ketahanan pembangunan kapal selam, namun dengan kapal 4 dan kapal 5 nantinya diharapkan mampu melakukan pembangunan kapal tipe sejenis, dengan asistensi dari kapal asing melalui kerjasama, PT.PAL ke depannya memperoleh ketahanan yang lebih bagus dalam kapal selam. Hal lain yang perlu dikembangkan untuk menunjang ketahanan alutsista adalah kesediaaan TNI

Hasil wawancara diuraikan sebagai berikut.

\footnotetext{
"Saat ini dari kelima poin yang saya sampaikan, PT.PAL masih bisa dikatakan belum memiliki ketahanan dalam pembangunan kapal selam. Bila dilihat dari manajemen, PT.PAL masih jauh memiliki kemampuan manajemen membangun kapal selam, material juga masih belum dapat teknologinya. SDM yang memiliki kemampuan tidak terlalu besar menyerap pengetahuan selama pelaksanaan OJT, Fasilitas masih banyak yang tambal sulam mengingat anggaran
} 
Tunggul Prasetyo, Armaidy Armawi, Dafri Agus Salim -- Evaluasi Kinerja KKIP Dalam Kerjasama Republik Indonesia-Korea Selatan Pada Pembangunan Kapal Selam

Untuk Mendukung Ketahanan Alutsista TNI Angkatan Laut

yang diminta tidak sesuai dengan yang direalisasikan pemerintah. Korea dalam kerjasama pembangunan ini sebenarnya terbuka namun demikian untuk design2 yang top secreet mereka juga tidak dapat memberikan kepada pihak Indonesia. Secara prosentase rata-rata mungkin PT.PAL tidak sampai memiliki 50\% dalam ketahanan pembangunan kapal selam, namun dengan kapal 4 dan kapal 5 nantinya diharapkan juga dibuat dengan tipe sejenis, maka dengan asistensi dari galangan kapal asing melalui kerjasama, PT.PAL ke depannya memperoleh ketahanan yang lebih bagus dalam penyediaan kapal selam.

Terakhir adalah kebijakan, TNI AL selaku user tentunya diharapkan juga terus turut menggunakan produksi yang akan dikembangkan oleh PT PAL dan KKIP selaku kepanjangan pemerintah tetap mendorong dan menjaga serta mengembangkan kebijakan yang telah ada dalam pembangunan kapal selam." (Wawancara dengan Marsdya TNI (Purn) Eris Herryanto, tanggal 5 April 2016).

Hasil analisis di atas menunjukkan bahwa evaluasi terhadap pemenuhan tujuan ketahanan alutsista belum dapat terpenuhi. Pemahaman mengenai pemenuhan tujuan ketahanan alutsista sendiri merupakan kemandirian industri pertahanan baik dalam memproduksi, menggunakan, dan merawat. Hasil evaluasi pada kemandirian industri pertahanan baik dalam memproduksi, menggunakan, dan merawat yang belum terpenuhi sebenarnya bagian dari hambatan baik dari faktor teknis maupun prosedural pada hasil temuan pada evaluasi terhadap keberlanjutan alutsista di atas. Ke depannya apabila hambatan baik prosedur maupun teknis tersebut dihilangkan dan proses produksi dapat dipenuhi, maka satu hal yang harus diperhatikan adalah kesediaaan TNI dengan menggunakan produksi pertahanan Indonesia.

\section{SIMPULAN}

Hasil temuan menunjukkan bahwa bentuk kerjasama yang dilaksanakan antara Indonesia-Korea Selatan adalah sebagai berikut.

Pertama, terdapat beberapa dasar kebijakan dalam kerjasama pemerintah Indonesia dengan Republik Korea, yaitu (1). MOM antara pemerintah Indonesia dengan Republik Korea tanggal 2-4 September 2013 tentang $3^{\text {rd }}$ Defense Industry Cooperation Committee Meeting. (2) MOM antara pemerintah Indonesia dengan Republik Korea tanggal 28-29 August 2013 tentang $1^{\text {st }}$ Defense Industry Cooperation Committee Meeting. (3) Keputusan Ketua Harian KKIP Nomor KEP/15/KKIP/XII/2013 tanggal 17 Desember 2013 tentang penugasan kepada PT PAL Indonesia (persero) dalam pembangunan kapal selam ke 3. (4) Keputusan Ketua Harian KKIP Nomor KEP/04/ XII/2012 tanggal 20 Desember 2012 tentang penguasaan teknologi kapal selam, dimana skema yang dijalankan atas dasar Local Production/Joint Production pembahasan amandemen kontra dan Joint Operation Agreement dengan DSME sesuai dengan skema yang digarapkan oleh pemerintah Indonesia. Kerjasama tersebut melibatkan transfer teknologi dimana Kemhan dapat mengirimkan tenaga-tenaga ahli yang dikirim pemerintah tidak hanya sebatas learning by seeing (belajar dengan cara mengamati), namun juga learning by doing (belajar dengan cara mempraktikkan). Selanjutnya dengan adanya kerjasama ini maka pihak Indonesia sebelum memulai produksi satu unit kapal selam akan membangun sejumlah infrastrukturnya terlebih dahulu, sehingga ke depan bisa dilanjutkan dengan produksi secara mandiri. Secara keseluruhan mekanisme pembangunan kapal selam yang antara Indonesia-Korea Selatan 
dilakukan di bawah kerangka defense offset yang pada dasarnya adalah proses pembelian atau investasi timbal balik yang disepakati oleh produsen atau pemasok persenjataan sebagai imbalan dari kesepakatan pembelian jasa dan barang-barang militer.

Kedua, terdapat beberapa alasan untuk menjalin kerjasama Indonesia-Korea Selatan dalam pembangunan kapal selam, yaitu (1) Kebutuhan Indonesia akan membangun industri pertahanan dimana industri pertahanan itu sendiri memiliki berbagai efek menguntungkan baik dari segi peningkatan postur pertahanan namun juga nilai Indonesia di mata negara dunia lainnya. Dengan kemandirian dalam memenuhi dan mengelola peralatan alutsista maka Indonesia dapat melepaskan diri dari ketergantungan. Di sisi lain, berbagai kekurangan kondisi yang dimiliki Indonesa dari SDM, pendanaan, dan penguasaan teknologi menjadi keterbatasan dalam pengembangan industri pertahanan selanjutnya, khususnya pembangunan kapal selam yang memiliki kerumitan paling tinggi dibandingkan dengan alutsista yang lainnya. (2) Pemilihan kerjasama dengan negara Korea Selatan karena adanya riwayat hubungan bilateral sebelumnya, dimana Indonesia dan Korea Selatan berada dalam posisi yang saling melengkapi, yakni kedua negara tersebut berpotensi untuk mengisi satu sama lain. Ini tercermin dalam kondisi masingmasing negara yang masih membutuhkan negara lainnya untuk melengkapi kebutuhan dalamnegerinya.

Ketiga, evaluasi Pelaksanaan Kerjasama Indonesia-Korea Selatan dalam pembangunan kapal selam menunjukkan bahwa (1) Evaluasi terhadap kebutuhan alutsista telah terpenuhi dengan tersedianya dua kapal dari tiga kapal yang seharusnya. Sementara satu kapal yang sedianya menjadi bentuk TOT masih mengalami hambatan karena belum terpenuhinya beberapa spesifikasi sesuai yang disyaratkan oleh Korea Selatan. (2) Evaluasi terhadap keberlanjutan alutsista yang mengacu kepada pemahaman pemenuhan tujuan ketahanan secara mandiri belum terpenuhi. Hal ini dikarenakan pada kenyataannya pelaksanaan kerjasama tersebut mengalami berbagai hambatan, yaitu (a) bahan yaitu baja yang belum dapat diproduksi oleh PT. Krakatau Steel, (b) kurangnya pendanaan, (c) penguasaan manajemen baik secara SDM maupun teknologi yang kurang. (3) Evaluasi terhadap pemenuhan tujuan ketahanan alutsista menunjukkan belum dapat terpenuhi. Pemahaman mengenai ketahanan alutsista dirujukkan pada kemandirian industri pertahanan baik dalam memproduksi, menggunakan, maupun merawat. Hasil temuan pada evaluasi ini sebenarnya merupakan dampak dari evaluasi terhadap keberlanjutan alutsista di atas.

Selanjutnya, berdasarkan analisis dari hasil penelitian dan kesimpulan di atas, peneliti memberikan beberapa rekomendasi yang dapat dijadikan bahan pertimbangan.

Pertama, berdasarkan kendala yang dihadapi oleh Komite Kebijakan Industri Pertahanan (KKIP) dalam memberikan rekomendasi bagi kerjasama kapal selam, peneliti menyarankan agar para pejabat Komite Kebijakan Industri Pertahanan untuk melakukan regulasi yang memungkinkan KKIP mampu turut andil terhadap proyek kerjasama yang telah berlangsung sebelum digulirkannya UU No. 16 Tahun 2012, sehingga pelaksana kontrak tetap tunduk pada regulasi Pemerintah Indonesia

Kedua, kepada pihak Kementerian yang membawahi Badan Usaha Milik Negara, perlu menginventarisir BUMN yang bergerak di bidang industri pertahanan, 
sehingga dapat dijadikan bahan untuk melaksanakan dan mengadakan infrastruktur yang dibutuhkan oleh BUMN ketika akan melaksanakan transfer of technology. Hal ini bercermin dari PT PAL Indonesia (Persero) yang belum siap untuk melaksanakan transfer of technology yang nantinya dapat menghambat proses revitalisasi industri pertahanan.

Ketiga, sepintas sistem MEF (Minimum Esensial Force) dianggap arif melihat dari kekurangan anggaran yang dimiliki negara untuk sektor pertahanan. Tetapi langkah ini sebenarnya bukan saja mengabaikan pentingnya kekuatan militer, melainkan pula merupakan jalan pikir yang tidak membangun. Jika hal ini sudah ditentukan, pengembangan komponen utama, komponen cadangan, dan komponen pendukung dapat diarahkan pada satu tujuan yang jelas, sehingga apa yang disebut minimum dapat dielaborasi dengan kriteria dan kebutuhan yang jelas. Hal ini untuk menciptakan perimbangan, realisasi pengadaan sistem senjata baru sebagaimana dicantumkan dalam Renstra harus sesuai jadwal. Selain itu, nampaknya perlu penambahan kuantitas pengadaan sistem senjata baru dalam Renstra. Pendapat ini berangkat dari basis pemikiran mendasar yaitu kepentingan nasional. Kepentingan nasional harus mendasari perencanaan kekuatan, bukan anggaran yang mendasari perencanaan kekuatan.

\section{DAFTAR PUSTAKA}

Bakrie, Connie Rahakundini M.Si., 2007, Pertahanan Negara dan Postur TNI Ideal, Edisi Pertama, Jakarta, Yayasan Obor Indonesia.

Murray, Stuart, 2016. Lihat \& Ketahui: Kapal
Selam, Jakarta, Elex Media Computindo. SIPRI, 2014, Belanja Pertahanan NegaraNegara ASEAN Tahun 2014.

\section{Peraturan Perundangan}

Undang Undang Nomor 3 Tahun 2002 tentang Pertahanan Negara.

Undang Undang Nomor 34 Tahun 2004 tentang Tentara Nasional Indonesia.

Undang Undang Nomor 15 Tahun 2012 tentang Industri Pertahanan.

Menteri Pertahanan RI, Peraturan Menteri Pertahanan RI Nomor 02 Tahun 2010 tanggal 5 Februari 2010 tentang Minnimun Essential Forces Komponen Utama.

Menteri Pertahanan RI, Peraturan Menteri Pertahanan RI Nomor 03 Tahun 2008 tanggal 18 Februari 2008 tentang Buku Putih Pertahanan.

$\mathrm{KEP} / 12 / \mathrm{KKIP} / \mathrm{XII} / 2013$ tanggal 17 Desember 2013 tentang Penunjukan PT PAL Indonesia (Persero) sebagai Lead integrator Alat Utama Sistem Senjata Matra Laut

KEP/15/KKIP/XII/2013 tanggal 17 Desember 2013 tentang Penugasan Kepada PT PAL Indonesia (persero) Dalam Pembangunan Kapal Selam ke 3

\section{Wawancara}

1. BJ. Habibie

2. Laksamana Muda TNI (Purn) Rachmad Lubis

3. Mayor Jenderal TNI (Purn) Judy Harianto

4. Marsekal Madya TNI (Purn) Erris Herryanto

5. Laksamana Pertama TNI Suryo Djati Prabowo

6. Dr. Timbul Siahaan

7. Kolonel Laut Oki Samudra, SE MM 